\title{
28. MODERN FLUID FLOW IN THE CASCADIA ACCRETIONARY WEDGE: A SYNTHESIS
}

\author{
Bobb Carson $^{2}$ and Graham K. Westbrook ${ }^{3}$
}

\begin{abstract}
The Cascadia Margin is characterized by rapid pore fluid expulsion from a thick sedimentary section during the accretion process. Ocean Drilling Program (ODP) Leg 146 focused particularly on the nature and movement of these fluids. The results, summarized below, define the first comprehensive characterization of flow within a modern accretionary prism. They reflect post-cruise analysis of seismic and logging data, returned samples, packer test results, data collected over 9.5 months at the instrumented borehole seal deployed at Hole 892B, and pump tests conducted at the same site from the submersible Alvin.

Fluid brought to the margin is originally incorporated in sediments deposited in Cascadia Basin. Initial deformation of these turbidite/hemipelagic deposits off Oregon and Vancouver Island occurs $\sim 6 \mathrm{~km}$ seaward of the topographic toe of the prism and is manifested by a series of blind thrust faults that exhibit both positive and negative polarity seismic reflections. Velocity data and sidescan sonar suggest that significant dewatering occurs in this proto-thrust zone. Further landward, deformation is manifested by anticlinal folding and imbricate thrust faulting.

Based on long-term $\left(>2 \times 10^{5} \mathrm{yr}\right)$ total pore volume loss off Oregon, the seawardmost $18 \mathrm{~km}$ of the prism is estimated to discharge fluid at rates of $3.2 \times 10^{-12}$ to $2.9 \times 10^{-11} \mathrm{~m}^{3} \mathrm{~m}^{-2} \mathrm{~s}^{-1}(0.1-0.9 \mathrm{~mm} / \mathrm{yr})$. Although the relative importance of dispersed versus focused flow to the total discharge is unknown, faults are clearly important pathways along which pore fluids are lost to the accreted section. Detailed fluid flow studies on Leg 146 concentrated on focused flow along fault zones, particularly a fluidactive thrust fault penetrated by Site 892 .

Thermal anomalies define episodic flow events presumably driven by variation in fluid pressure. The instrumented borehole seal at Site 892 recorded a temperature excursion of $4^{\circ} \mathrm{C}$ at 100 meters below seafloor (mbsf) over 5.5 months, a decline in pore pressure from $70 \mathrm{kPa}$ above hydrostatic at hole shut-in to $2 \mathrm{kPa} 5$ months later, and an attenuated tidal signal in the pressure record that exhibits short-period fluctuations. Flow may respond to pressure variations on a variety of temporal scales, but shoaling of the bottom-simulating reflector (BSR) and calculated darcian flow based on observed pressures and measured transmissivities indicate an average flow within the fault zone at Site 892 of $\sim 1 \times 10^{-6} \mathrm{~m}^{3} \mathrm{~m}^{-2} \mathrm{~s}^{-1}\left(\sim 3.2 \times 10^{4} \mathrm{~mm} / \mathrm{yr}\right)$. The seafloor heat flow anomaly, however, requires that present flow rates along the fault zone cannot have continued for more than about $400 \mathrm{yr}$.

Flow episodicity in the fault zone at Site 892 is inferred to be a direct function of variations in the pressure field, and an indirect result of the pressure dependence of the hydraulic conductivity (permeability). Both laboratory tests on sediment from the fault zone and in situ hydrogeologic tests indicate that fractures within the fault zone control and localize flow. Pore pressures in excess of 50\%-70\% lithostatic stress apparently dilate fractures and increase hydraulic transmissivity by at least two orders of magnitude relative to closed fractures under near-hydrostatic conditions or to unfractured wall-rock. The marked dependence of fracture permeability on excess pore pressure and thus the effective confining stress yields a non-linear flow response in the fracture zone to pressure fluctuations.
\end{abstract}

\section{INTRODUCTION}

Ocean Drilling Program (ODP) Leg 146 was conceived to evaluate the role of fluid flow in the structural development of the Cascadia accretionary wedge and to determine how that flow controls the composition, distribution, concentration, and flux of biogeochemical species. The Initial Reports volume (Westbrook, Carson, Musgrave, et al., 1994) details both primary and secondary evidence for fluid advection on the Cascadia Margin. This paper does not review that information, but examines work derived from those data or completed subsequent to their publication, and focuses on quantitative estimates of, and constraints on, the physical movement of fluids within the wedge.

Most of the post-cruise hydrogeologic investigations concentrated on the Oregon margin. In part, this focus was dictated by the success of the packer experiment and the instrumented borehole seal (Circulation Obviation Retrofit Kit, CORK; Davis et al., 1992) at Hole 892 B. In contrast, at Site 889 off Vancouver Island the packer experiment failed (Westbrook, Carson, Musgrave, et al., 1994), the

'Carson, B., Westbrook, G.K., Musgrave, R.J., and Suess, E. (Eds.), 1995. Proc. ODP, Sci. Results, 146 (Pt. 1): College Station, TX (Ocean Drilling Program).

${ }^{2}$ Department of Earth and Environmental Sciences, Lehigh University, 31 Williams Drive, Bethlehem, PA 18015, U.S.A.

${ }^{3}$ School of Earth Sciences, University of Birmingham, P.O. Box 363, Edgbaston, Birmingham B15 2TT, United Kingdom. borehole seal did not hydraulically isolate the hole, and the CORK thermistor string and pressure gauge were damaged during deployment (Davis et al., this volume). As a result, there are no in situ hydrogeologic data from the Vancouver section.

Because Sites 889 and 890 on the Vancouver margin were placed to evaluate dispersed fluid flow unrelated to faulting, our failure to determine hydrogeologic parameters that affect flow patterns and rates at this location means that Leg 146 results do not elucidate the problem of dispersed water flow or discharge. Although the velocityporosity relationships derived by Jarrard et al. (this volume) are fundamental to establishment of a regional water budget (see below) and consolidation-induced pore fluid expulsion models, they shed no light on the relative importance of dispersed versus focused fluid discharge. The data from Oregon Sites 891 and 892, however, materially advance our understanding conditions in an accretionary wedge under which flow is focused along thrust faults.

\section{CALCULATED FLUID INVENTORY AND DERIVED DISCHARGE RATES OFF OREGON}

Accretion-induced porosity reduction and fluid loss is a fundamental subduction process that is recognized at numerous margins (Bray and Karig, 1985). In general, there is a progressive, landward loss in porosity, as average, depth-integrated porosity in basin sediments $(20 \%-30 \%)$ is approximately halved $(10 \%-15 \%)$ within 10 
$15 \mathrm{~km}$ landward of the topographic toe of the prism. Bekins and Dreiss (1992) presented an equilibrium model of fluid flow in deforming, saturated sediments, and calculated fluid production and dewatering rates for several margins based on convergence rate, sediment thickness, wedge taper, and porosity. Their calculations for the Vancouver portion of the Cascadia margin indicate rapid water loss $(\sim 1.4 \mathrm{~mm} /$ $\left.\mathrm{yr} ; 4.4 \times 10^{-11} \mathrm{~m}^{3} \mathrm{~m}^{-2} \mathrm{~s}^{-1}\right)$ at the topographic toe of the prism, but significantly lower production $\left(\sim 0.6 \mathrm{~mm} / \mathrm{yr} ; 1.9 \times 10^{-11} \mathrm{~m}^{3} \mathrm{~m}^{-2} \mathrm{~s}^{-1}\right)$ just 18 $\mathrm{km}$ landward. In contrast, Hyndman et al. (1993b) and Yuan et al. (1994), based on thermal modeling and seismic velocity analysis, suggest that significant dewatering ( $>33 \%$ of initial fluid content) occurs seaward of the prism, and that maximum fluid expulsion rates $\left(\sim 1.3 \mathrm{~mm} / \mathrm{yr} ; 4 \times 10^{-11} \mathrm{~m}^{3} \mathrm{~m}^{-2} \mathrm{~s}^{-1}\right)$ occur $20-30 \mathrm{~km}$ landward of the toe of the prism. Other workers have suggested that dewatering is suppressed at the topographic toe of the prism off Oregon (Lewis, 1992; Carson et al., 1994) and elsewhere (e.g., Barbados; Bangs et al., 1990).

\section{Procedure}

Cochrane et al. (1988) analyzed seismic stacking velocities from the multichannel seismic (MCS) lines used to locate the Leg 146 drilling sites off Oregon, and ocean-bottom seismometer (OBS) refraction data on the lower continental slope and adjacent portions of Cascadia Basin to establish the $P$-wave velocity distribution. From these data, the authors infer the two-dimensional porosity distribution, using densities assumed in synthetic trace modeling that were derived from velocity using Hamilton's relationship (1978). Yuan et al. (1994) found that the velocity-porosity curve derived by Hyndman et al. (1993a) for the Nankai margin fit well the shipboard velocity/porosity measurements of Cascadia Basin sediments made on ODP Leg 139 (Davis, Mottl, Fisher, et al., 1992), and used that relationship to predict porosity from the sediment velocities. To infer the porosity distribution in this paper, we combine the velocity distributions of Cochrane et al. $(1988,1994 b)$ with the velocity-porosity relationships established by Jarrard et al. (this volume) for low velocity $\left(V_{p} \leq 2 \mathrm{~km} / \mathrm{s}\right.$ ) Cascadia margin sediments and the Hyndman et al. (1993a) relationship for sediments with compressional wave velocities $>2 \mathrm{~km} / \mathrm{s}$ (Fig. 1).

Because small-scale fracturing is ubiquitous in much of the accreted section sampled by drilling, we applied the velocity-porosity relationship for fractured sediments (Jarrard et al., this volume) where applicable (porosity $(n) \geq 0.38$ ) to the accreted slope sediments, and utilized the relation defined by Hyndman et al. (1993a) at greater depths. Similarly, for proximal and distal Cascadia Basin sediments,

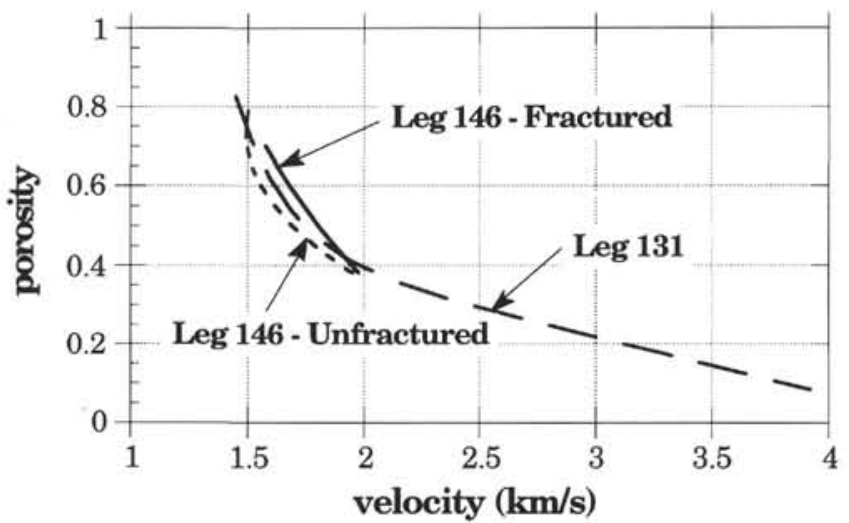

Figure 1. Velocity-porosity relationships used to calculate fluid volumes. Leg 146 regression lines are based on interpretation of downhole logs by Jarrard et al. (this volume). Leg 131 results were derived by Hyndman et al. (1993a). we used the unfractured porosity-velocity relationship derived from Site 888 (Jarrard et al., this volume) at $\mathrm{n} \geq 0.38$, and the Hyndman et al. (1993a) curve at greater depths. In the proto-thrust zone (Fig. 2), where faulting clearly occurs but the extent of microfracturing is unknown, we used the Hyndman velocity-porosity relation as it falls between the fractured and unfractured curves of Jarrard et al. (this volume). Although the velocity-porosity curve defined by Hyndman et al. (1993a) is strictly applicable only at $\mathrm{n} \geq 0.30\left(V_{p}<2.5 \mathrm{~km} / \mathrm{s}\right)$, we have utilized it for deeply-buried sediments with velocities as high as $4.4 \mathrm{~km} / \mathrm{s}$. Although the curve almost certainly underestimates porosities at velocities $>3 \mathrm{~km} / \mathrm{s}$ (see fig. 10 in Yuan et al., 1994), it is the best relationship available for the upper portions of the sediment column where porosities and pore fluid volumes are high.

Pore-water volume is obtained by integrating velocity-derived porosity Jarrard et al. (this volume) and Hyndman et al. (1993a) profiles over the sediment thickness (dashed curves in upper diagram, Fig. 3). Porosity-depth regression lines are:

1. distal Cascadia Basin: $\mathrm{n}=0.4891 \times \mathrm{e}^{-0.0004(\mathrm{~m})}, \mathrm{r}=-0.9745$, 7 d.f.;

2. proximal Cascadia Basin: $\mathrm{n}=0.4533 \times \mathrm{e}^{-0.0003(\mathrm{~m})}, \mathrm{r}=-0.9906$, 7 d.f.;

3. proto-thrust zone: $\mathrm{n}=0.3852 \times \mathrm{e}^{-0.0002(\mathrm{~m})}, \mathrm{r}=-0.8983$, 6 d.f.;

4. marginal ridge: $\mathrm{n}=0.4071 \times \mathrm{e}^{-0.0002(\mathrm{~m})}, \mathrm{r}=-0.9168,11$ d.f.;

5. second ridge: $\mathrm{n}=0.4838 \times \mathrm{e}^{-0.0004(\mathrm{~m})}, \mathrm{r}=-0.9759,14$ d.f.

Fluid entrainment in Cascadia Basin is determined by subtracting the pore-water volume at a particular location from the comparable volume in the adjacent, landward position. Model pore-water volumes beneath the marginal and second ridges are determined by using the porosity profiles above and below the position of observed thrust faults (i.e., assuming that faulting at depths of $100-1000$ mbsf superimposed near-surface sediments over footwall deposits that were in consolidation equilibrium; solid curves in upper diagram, Fig. 3). The range in model pore-water volume reflects variation in the assumed depth to the fault and, in the case of the second ridge, whether 1-3 thrust packets elevated the section. Apparent expulsion rates are based on biostratigraphic ages of ridges. Predicted expulsion rates (Bekins and Dreiss, 1992; Hyndman et al., 1993b) are taken from comparable positions ( 3 and $18 \mathrm{~km}$ landward of prism toe) off Vancouver Island.

\section{Structure, Porosity Distribution, and Measured Fluid Expulsion}

Porosity declines from west to east in Cascadia Basin sediments located more than $6 \mathrm{~km}$ seaward of the topographic prism toe off Oregon (Fig. 2; Cochrane et al., 1994b). Because the velocity increases eastward at comparable sub-bottom depths, this change reflects either lateral textural variations or compaction associated with initial tectonic deformation.

Within $6 \mathrm{~km}$ of the topographic base of the prism (proto-thrust zone; Fig. 2), blind thrust faults with throws of $<20 \mathrm{~m}$, cut the Cascadia Basin section. These faults appear to act as fluid conduits, as sidescan sonar data exhibit anomalous reflectance indicative of expulsion-related diagenetic deposits (perhaps gas hydrates; Carson et al., 1994) in the surface sediments. Most of the blind thrusts exhibit reverse polarity reflections on seismic sections, indicative of low velocity, that may indicate local fabric dilation under elevated pore pressure (Moore et al., this volume). Because porosity is reduced $\sim 7 \%$ in shallow $(<1700 \mathrm{mbsf})$ sediments of the proto-deformation zone relative to basin sediments further offshore (Fig. 3), the thrust faults may be loci for fluid transport from the compacting sediments. The blind thrusts sole out in a developing décollement, a low velocity zone that may reflect underconsolidation (Cochrane et al., 1994a). Yuan et al. (1994) have attributed a similar decline in porosity off 

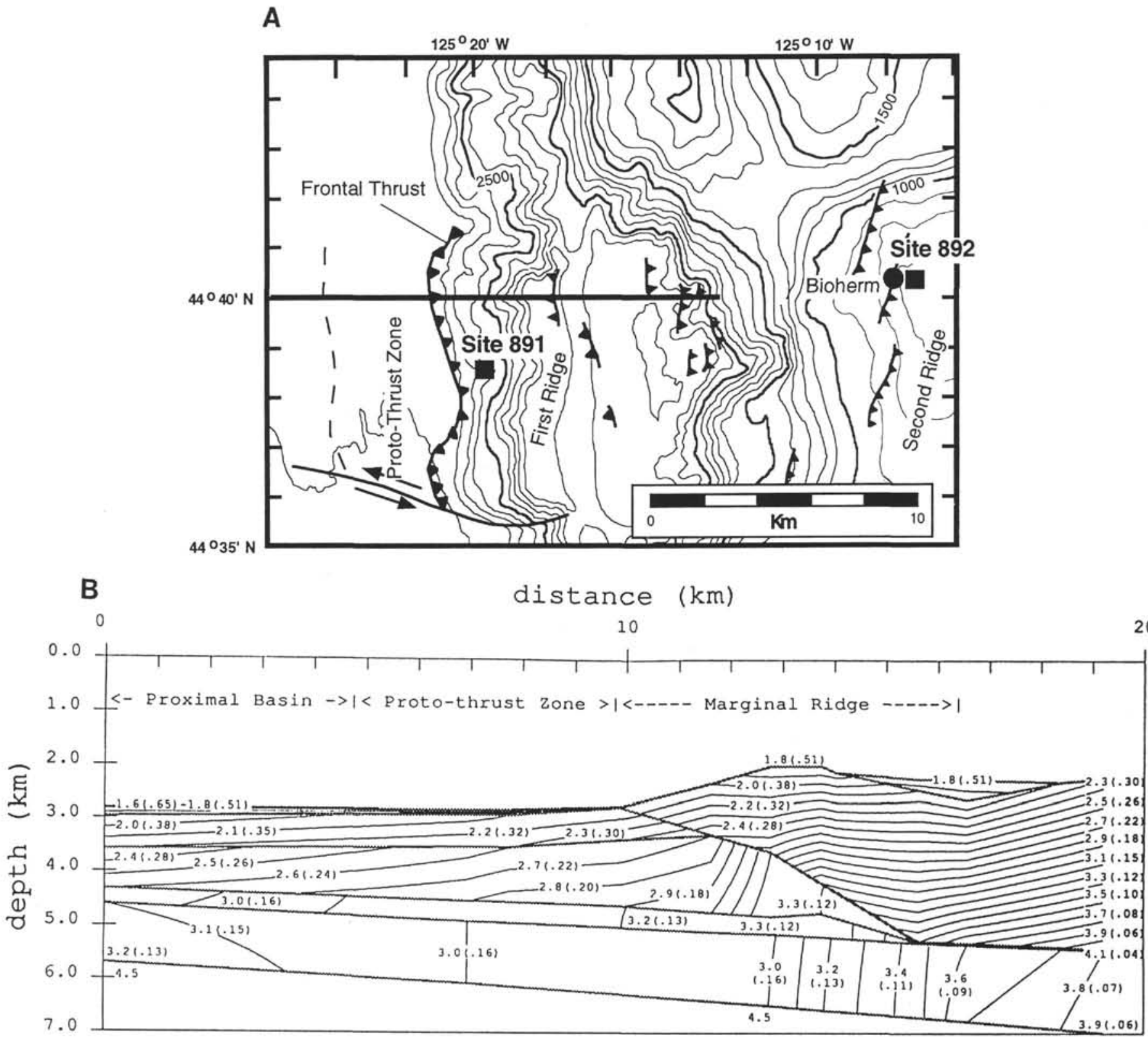

Figure 2. A. Location map of lower Oregon margin. Positions of ODP Sites 891 and 892 are plotted, as is the seismic velocity profile (Fig. 2B) at $44^{\circ} 40^{\prime}$ N. B. Velocity model of the sediments of Cascadia Basin and the lowermost continental slope off Oregon (from Cochrane et al., 1994b). Velocity contours are thin dark lines, velocity values are in $\mathrm{km} / \mathrm{s}$. Values in parentheses are porosity values inferred by Cochrane et al. (1994b), but are not the values used in this paper to calculate the fluid inventory.

Vancouver Island to horizontal tectonic consolidation and rapid fluid expulsion.

The marginal ridge (Fig. 2) is formed by a Pleistocene fault-propagation fold elevated by movement up the frontal thrust fault (Westbrook, Carson, Musgrave, et al., 1994). Velocity is lower at comparable depths beneath the seafloor in the ridge (above the frontal thrust) relative to the proto-deformation zone. This pattern of reduced velocity at the toe of the prism has been previously interpreted (Lewis, 1992; Yuan et al., 1994) to indicate higher subsurface porosity, perhaps as the result of microfracture formation. However, application of the fractured sediment velocity-porosity relation (Jarrard et al., this volume) indicates that pore fluid volume above $1700 \mathrm{mbsf}$ is elevated relative only to the proto-thrust zone (Fig. 3), and differs from pore volumes in distal and proximal regions of Cascadia Basin by less than $2 \%$. Diagenetic carbonate concretions, slabs, and beds, observed on submersible dives and imaged by side-scan sonar (Car- son et al., 1994), suggest that pore fluids either migrate preferentially to deep-seated strike-slip faults that cut across the margin, or feed into the proto-décollement in Cascadia Basin, in preference to flowing up the frontal thrust. Direct flow measurements at seafloor vent sites on the northern end of the marginal ridge yield flow that varies from $1 \times 10^{-6}$ to $6 \times 10^{-6} \mathrm{~m}^{3} \mathrm{~m}^{-2} \mathrm{~s}^{-1}\left(3.1 \times 10^{4}\right.$ to $1.9 \times 10^{5} \mathrm{~mm} / \mathrm{yr}{ }^{-1}$; Carson et al., 1990).

Further landward, the seismically-incoherent Pliocene section (second ridge) is cut by a series of out-of-sequence thrust faults (MacKay et al., 1992). One of these, penetrated at Site 892, is an active conduit for fluids as evidenced by massive accumulations of diagenetic carbonate (Carson et al., 1994), rapid, measured fluid expulsion $\left(2 \times 10^{-5} \mathrm{~m}^{3} \mathrm{~m}^{-2} \mathrm{~s}^{-1} ; 6.3 \times 10^{5} \mathrm{~mm} / \mathrm{yr}^{-1}\right)$ at the fault trace (Linke et al., 1994), upward displacement of the BSR and surficial occurrence of gas hydrates, presence of thermogenic hydrocarbons in pore waters, temperature anomalies in the fault zone up to $2.5^{\circ} \mathrm{C}$ 


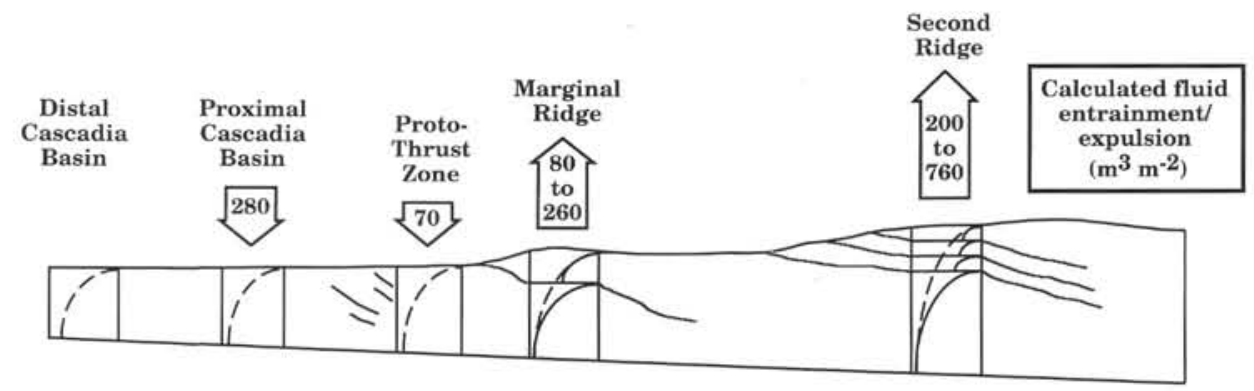

\begin{tabular}{|c|c|c|c|c|c|c|c|}
\hline 0.35 & 0.30 & 0.28 & 0.27 & \multicolumn{2}{|c|}{ Model parameters } & 0.17 & Average porosity \\
\hline \multirow[t]{2}{*}{1.7} & \multirow[t]{2}{*}{2.9} & \multirow[t]{2}{*}{3.4} & \multirow{2}{*}{4.5} & 2.0 & 4.0- & $6.0-$ & \multirow{2}{*}{ Thickness (km) } \\
\hline & & & & 2.5 & 4.5 & & \\
\hline 600 & 880 & 950 & 1200 & $\begin{array}{l}1280- \\
1460\end{array}$ & $\begin{array}{l}1320- \\
1860\end{array}$ & $\begin{array}{l}1100 \\
1120\end{array}$ & $\begin{array}{l}\text { Porewater volume } \\
\left(\mathrm{m}^{3} \mathrm{~m}^{-2}\right)\end{array}$ \\
\hline \multirow[t]{3}{*}{600} & 600 & 560 & 590 & & & 600 & $\begin{array}{l}\text { Porewater volume } \\
\text { above } 1700 \text { mbsf }\end{array}$ \\
\hline & -32 & $\cdot 7$ & $\begin{array}{l}7 . \\
22\end{array}$ & & & $\begin{array}{l}18 . \\
70\end{array}$ & $\begin{array}{l}\text { \% present volume } \\
\text { expelled }\end{array}$ \\
\hline & & & $\begin{array}{l}0.3- \\
0.9\end{array}$ & & & $\begin{array}{l}0.1- \\
0.8\end{array}$ & $\begin{array}{c}\text { Apparent rate of } \\
\text { expulsion }\left(\mathrm{mm} \mathrm{yr}^{1}\right)\end{array}$ \\
\hline \multicolumn{3}{|c|}{ Bekins and Dreiss, 1992} & 1.4 & \multirow{2}{*}{\multicolumn{2}{|c|}{4}} & 0.6 & \multirow{2}{*}{$\begin{array}{r}\text { Predicted rate of } \\
\text { expulsion }\left(\mathrm{mm} \mathrm{yr}^{1}\right)\end{array}$} \\
\hline \multicolumn{3}{|c|}{ Hyndman et al., 1993} & $<0.1$ & & & -0.5 & \\
\hline
\end{tabular}

Figure 3. Calculated fluid inventory for the Oregon Margin based on the velocity distribution in Figure 2 and in Cochrane et al. (1988; velocity structure beneath second ridge).

above the ambient temperature gradient (Westbrook, Carson, Musgrave, et al., 1994), and a post-drilling increase in temperature (to $4^{\circ} \mathrm{C}$ above ambient) at $100 \mathrm{mbsf}$ after the hole was shut in (Davis et al., this volume).

\section{Calculated Fluid Inventory and Rates of Expulsion}

The velocity-derived porosity generally declines from west to east across the Cascadia Basin/Oregon margin (Fig. 3), but because the section thickens nonuniformly, pore-water volume and derived fluid discharge vary irregularly. In Cascadia Basin, fluid is entrained to the sediment column by deposition. In contrast, because little sediment accumulates on the crest and flanks of the ridges after uplift, fluid is largely exported. In the proto-thrust zone, apparently both processes occur, with water entrained as turbidites and hemipelagic sediments accumulate on the distal portions of Astoria Fan, and fluids expelled as the section shortens and thickens in response to convergence. Comparison of the proto-thrust zone ( $\leq 6 \mathrm{~km}$ west of base-of-slope) with that beneath a proximal portion of Cascadia Basin $(10 \mathrm{~km}$ west of base-of-slope) indicates that the section has thickened (by deposition and thrust-faulting) by $500 \mathrm{~m}$, and although the pore-water volume has increased by $70 \mathrm{~m}^{3} \mathrm{~m}^{-2}$, pore fluid volume in the upper 1700 $\mathrm{m}$ is reduced by $40 \mathrm{~m}^{3} \mathrm{~m}^{-2}(\sim 7 \%)$.

The sections beneath the marginal ridge and the second ridge cannot be directly compared with the adjacent (seaward) sections, because thrust faulting has imported pore fluids to these locations by lateral displacement that clearly perturbs equilibrium porosity profiles formed by normal vertical accumulation. We have approximated the total fluid volume at these sites in two ways: (1) used seismic velocity data to infer the "present" porosity and calculated fluid volume by integrating the pore volume over the total thickness of the sedimentary section; and (2) used a porosity model which assumes that thrust-faulting superimposes one or more equilibrium porosity profiles (Carson et al., 1991). Comparison of these two pore-water volume estimates (Fig. 3) indicates that the present fluid volume beneath the marginal ridge $\left(1200 \mathrm{~m}^{3} \mathrm{~m}^{-2}\right)$ and the second ridge (1100-1120 $\mathrm{m}^{3} \mathrm{~m}^{-2}$ ) are substantially less than would be expected if thrust-faulting instantaneously superimposed equilibrium porosity profiles (1280$1460 \mathrm{~m}^{3} \mathrm{~m}^{-2}$ and $1320-1860 \mathrm{~m}^{3} \mathrm{~m}^{-2}$, respectively). If we assume that the observed porosity profile has evolved as a response to this tectonic thickening, less fluid has been evolved from the marginal ridge $\left(80-260 \mathrm{~m}^{3} \mathrm{~m}^{-2}\right)$ than from the second ridge $\left(200-760 \mathrm{~m}^{3} \mathrm{~m}^{-2}\right)$.

Biostratigraphy indicates that the first ridge was elevated $\sim 300,000$ yr BP (Kulm and Fowler, 1974) while the second ridge is younger than 1-2 × $10^{6} \mathrm{yr}$ (Westbrook, Carson, Musgrave, et al., 1994). Calculated, time-averaged expulsion rates of $0.3-0.9 \mathrm{~mm} \mathrm{yr}^{-1}$ $\left(9.5 \times 10^{-12}\right.$ to $\left.2.9 \times 10^{-11} \mathrm{~m}^{3} \mathrm{~m}^{2} \mathrm{~s}^{-1}\right)$ for the first ridge and $0.1-0.8 \mathrm{~mm}$ $\mathrm{yr}^{-1}\left(3.2 \times 10^{-12}\right.$ to $2.5 \times 10^{-11} \mathrm{~m}^{3} \mathrm{~m}^{2} \mathrm{~s}^{-1}$; Fig. 3$)$ suggest relatively uniform rates of fluid loss across the lower margin. This pattern differs markedly from the non-linear decline in dewatering rates calculated by Bekins and Dreiss (1992; Fig. 3). Constant discharge would also contradict the model results reported by Hyndman et al. (1993b), Wang et al. (1993), and Wang (1994) which show a discharge maximum of $\leq 1.3 \mathrm{~mm} \mathrm{yr}^{-1}\left(\leq 4.1 \times 10^{-11} \mathrm{~m}^{3} \mathrm{~m}^{2} \mathrm{~s}^{-1}\right)$ at distances ranging from $\sim 15-35 \mathrm{~km}$ landward of the toe of the prism (Fig. 3). However, the uncertainties in the inventory model expulsion rates are sufficiently large across the short segment of the lower margin considered (Fig. 3) that this model can neither confirm nor refute a pattern of maximum discharge landward of the marginal ridge.

\section{FLUID PRESSURES}

Fluid expulsion from any accretionary wedge is driven by a pressure gradient whose lower limit is defined by hydrostatic pressure at the seafloor and upper limit by lithostatic pressure within the accreted section. Previous work, as summarized by Moore and Vrolijk (1992), suggested that pressures in many prisms must approach lithostatic to induce the observed hydrofracturing and dilation of fault zones and enhance permeability. Establishment of positive local pressure gradients to expel interstitial fluids from rock matrix to aquifers (faults or high permeability strata) requires that pressure in these conduits cy- 
cle over time (Brown et al., 1994). However, neither have actual pressures in accretionary fault zones been measured directly prior to Leg 146 , nor has the pressure dependence of permeability in these aquifers been established.

Evidence for elevated fluid pressures on the Cascadia margin is based on seismic modeling (Hyndman et al., 1993b; Cochrane et al., 1994b; Moore et al., this volume), critical taper analysis (Davis and Hyndman, 1989), experimental results (Tobin et al., this volume), geotechnical properties of core samples (Moore et al., 1994; Brown, this volume; Moran et al., this volume), a packer test (Screaton et al., this volume), and a 9-month, post-drilling, pressure record at Hole 892B (Davis et al., this volume).

High-amplitude, negative-polarity seismic reflections are observed from faults in the proto-deformation zone, as well as from portions of the frontal thrust fault, the décollement, and, perhaps, the outof-sequence thrust on the second ridge (Moore et al., this volume). Synthetic waveform modeling on the frontal thrust at Site 891 indicates that the reflection from the middle splay of the fault is the result of a thin $(2-9 \mathrm{~m})$, relatively low-velocity zone $(100-300 \mathrm{~m} / \mathrm{s}$ lower than wall rock velocities) in the plane of the fault. Tobin et al. (this volume) have further established, by tests on lithologically similar samples taken from both wall rock and fault zone at Sites 891 and 892 , that $P$-wave velocity decreases $80-350 \mathrm{~m} / \mathrm{s}(8 \%-18 \%)$, as pore pressure (at constant confining stress) approaches lithostatic pressure (Fig. 4). Comparison of these experimental data with the modelled seismic velocities indicates that portions of the frontal thrust fault, characterized by negative-polarity reflections, probably exhibit pore pressures which are $\geq 70 \%$ of the lithostatic pressure $\left(\lambda^{*}=\right.$ (pore pressure-hydrostatic pressure)/(confining pressure-hydrostatic pressure) $\geq 0.70$ ). Tobin et al. (this volume) suggest that fault slip, hydrofracturing, and/or episodic flow may only occur at $\lambda^{*}=0.70-1.0$, and that pore pressures cycle between hydrostatic $\left(\lambda^{*}=0\right)$ and these higher values, as sections of the same fault exhibit both positive- and negative-polarity reflectors. They note, however, that high-amplitude negative-polarity reflections, while indicative of elevated fluid pressure, do not directly imply greatly increased porosity or permeability.

Corroborative evidence for elevated fluid pressures in Cascadia fault zones comes from physical properties of samples and associated geotechnical tests. Based on the undrained shear strength/effective overburden pressure ratio $\left(S_{u} / P_{o}^{\prime}\right.$; a proxy for estimating sediment

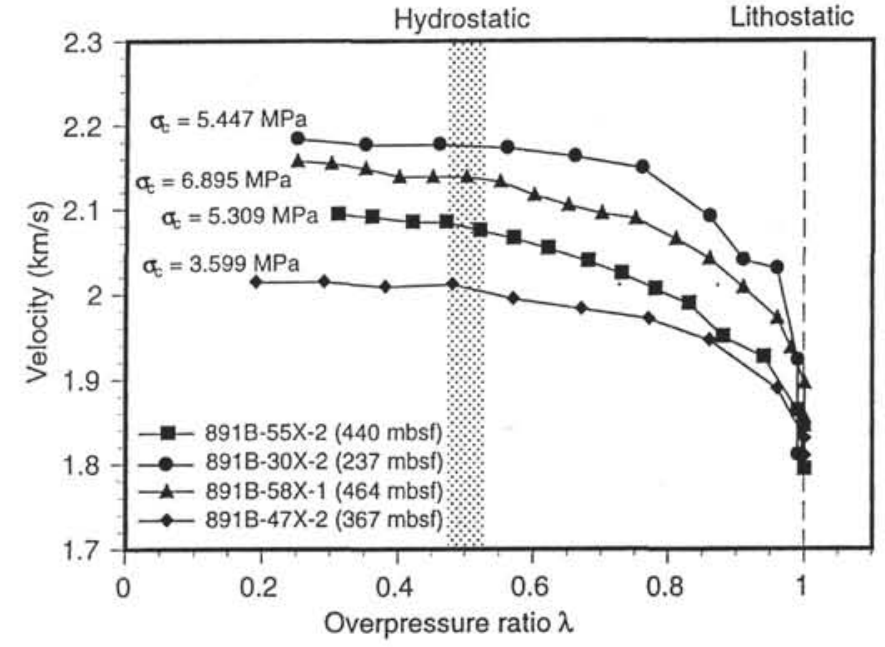

Figure 4. Selected $P$-wave ultrasonic velocity versus overpressure ratio determinations for Site 891 samples (from Tobin et al., this volume). The overpressure ratio $\lambda$ is hydrostatically uncompensated; it may be related to $\lambda^{*}$ by $\lambda^{*}=\left(p_{c} \lambda-p_{h}\right) /\left(p_{c}-p_{h}\right)$, where $p_{c}=$ confining pressure and $p_{h}=$ hydrostatic pressure (H. Tobin, pers. comm., 1995). At $\lambda=0.5, \lambda^{*}=0$ (hydrostatic pressure); at lithostatic pressure, both $\lambda$ and $\lambda^{*}=1.0$. These data are the basis for the conclusion that $\lambda^{*} \geq 0.70(\lambda \geq 0.85)$ is necessary to produce the seismic velocity minimum within the frontal thrust fault required to generate the observed reverse polarity reflection.

stress history) and one-dimensional consolidation tests, Moran et al. (this volume) conclude that sediments in the middle splay of the frontal thrust fault at Site 891 (447 mbsf) support excess pore pressures of 8.3-8.9 MPa, equivalent to $\lambda * \sim 0.84-0.98$. Similarly, consolidation tests on samples from Site 892 (Brown, this volume) clearly indicate that the faulted section below $68 \mathrm{mbsf}$ is underconsolidated (Fig. 5A) and subject to excess pore pressures $\leq 960 \mathrm{kPa}(\lambda *=0.7-$ 0.8 ; Fig. 5B). Above $68 \mathrm{mbsf}$, Site 892 deposits appear to be normally consolidated, although they exhibit pervasive stratal disruption from
A

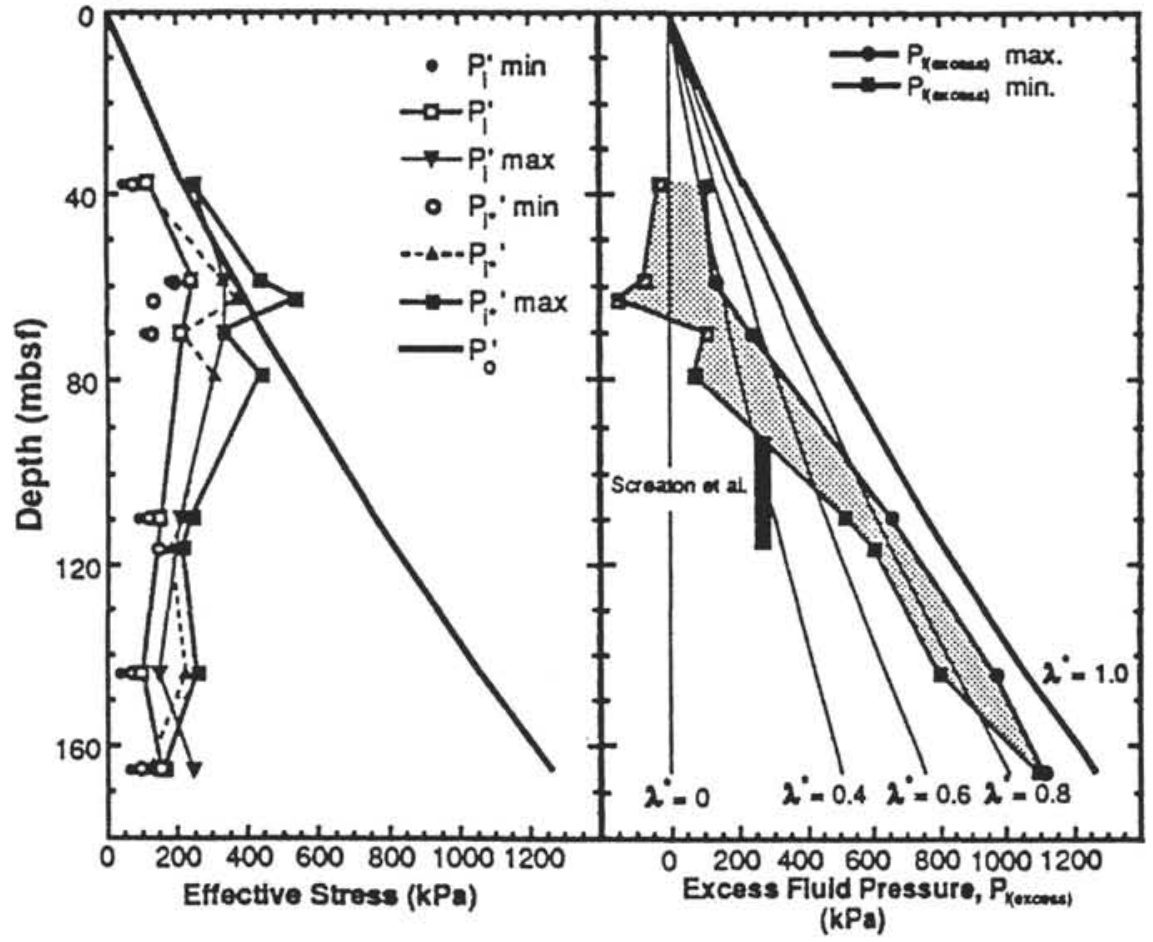

Figure 5. A. Estimates of maximum past consolidation stress to which the sediment section at Site 892 has been exposed. $P_{o}{ }^{\prime}$ is the lithostatic stress under hydrostatically pressured conditions. $P_{i}^{\prime}$ is the maximum past consolidation stress estimate obtained from the void ratio $(e)$ versus $\log \sigma_{i}^{\prime}$ (isotropic stress) plots. $P_{i^{\prime}}{ }^{\prime}$ is the maximum past consolidation stress estimate obtained from the log K (permeability) versus $\log \sigma_{i}^{\prime}$ (isotropic stress) plots. B. The excess fluid pressure $\left(P_{\text {flexcess }}\right)$ is shown as a function of maximum past consolidation stress $\left(P_{i^{*}}\right)$ and effective overburden stress under hydrostatic conditions $\left(P_{o}\right)$. Heavy bar indicates in situ fluid pressure recorded during packer test (Screaton et al., this volume). From Brown (this volume). 


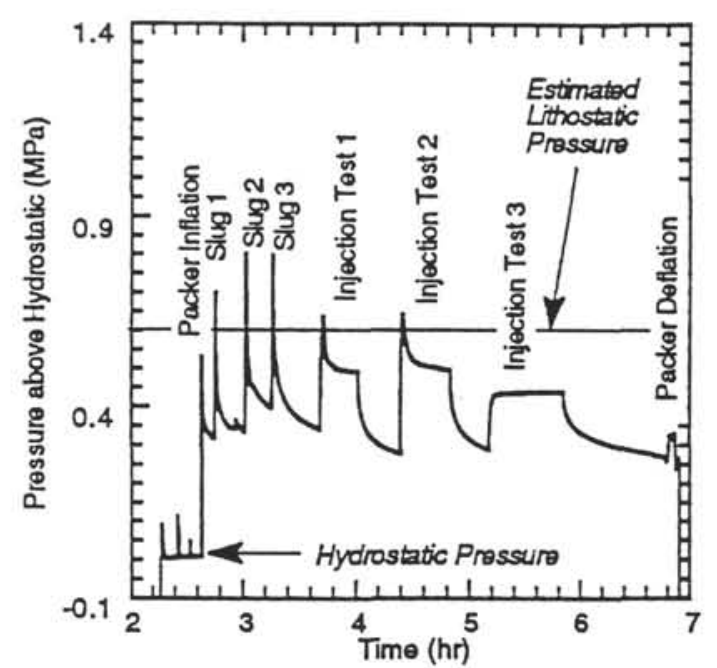

Figure 6. Downhole pressure record from the packer test at Site 892, relative to hydrostatic pressure. The horizontal line represents estimated lithostatic pressure at 93.5 mbsf, assuming an overlying sediment bulk density of 1.700 $\mathrm{Mg} \mathrm{m}^{-3}$. From Screaton et al. (this volume).

38-68 mbsf. Based on the consolidation tests, pore pressure above 68 mbsf is inferred to be nearly hydrostatic.

A successful packer test at Site 892 directly monitored fluid pressures (Screaton et al., this volume), after casing had been set and grouted to a depth of $93.6 \mathrm{mbsf}$, and the hole extended to $175 \mathrm{mbsf}$. Decay of slug tests and constant-rate injection tests (Fig. 6) indicate pore pressure of $250-325 \mathrm{kPa}$ above hydrostatic at the time of the test. Davis et al. (this volume) have suggested that pressures observed during the packer test may not be true formation pressures, but reflect partial decay of original and drilling-induced pressures. As Screaton et al. (in press) point out, any anomalous drilling-induced pressure should have decayed away prior to the packer test. These authors suggest that the pressures measured during the packer test $(250-325 \mathrm{kPa})$ probably do not deviate significantly from pre-drilling pore pressures. If this is the case, $\lambda^{*}=0.4-0.5$ in the faulted interval at Site 892.

Hourly pressure data recovered from the borehole seal at Site 892 10 months after deployment do not define ambient pressures that approach lithostatic. On the contrary, rather than increasing after shutin, the in-hole pressures decayed exponentially from an initial $70 \mathrm{kPa}$ $\left(\lambda^{*}=0.12\right)$ to an equilibrium value of $13 \mathrm{kPa}$ above hydrostatic $\left(\lambda^{*}\right.$ $=0.02 ;$ Fig. 7). Davis et al. (this volume) speculate that the observed decay is simply the latter portion of a pressure dissipation curve from initial values possibly as high as $\sim 500 \mathrm{kPa}$ above hydrostatic $\left(\lambda^{*}\right.$ $\sim 0.8$ ). The pressure decline can be attributed to emplacement of the drill hole (Screaton et al., in press), which provides a vertical fluid conduit, perhaps connecting the active flow zone $(\sim 100 \mathrm{mbsf}$ as defined by a temperature anomaly; Davis et al., this volume) with lower pressure zones within the uncased portion of the hole that were previously isolated. Alternatively, fluid pressure may have dissipated horizontally rather than vertically, as pressures along fault zones may be laterally heterogeneous and time-variant (Brown et al., 1994).

\section{HYDRAULIC CONDUCTIVITY}

\section{Laboratory Determinations}

One-dimensional consolidation tests and constant flow permeability tests on samples from Sites 891 and 892 yield estimated in situ hydraulic conductivities of $10^{-7}$ to $10^{-9} \mathrm{~cm} \mathrm{~s}^{-1}$ in sections unaffected by faulting, and values two-four orders of magnitude higher $\left(10^{-5}\right.$ to $10^{-7} \mathrm{~cm} \mathrm{~s}^{-1}$ ) in pressured, faulted intervals (Brown, this volume; Moran et al., this volume). This 2 orders of magnitude contrast in con-

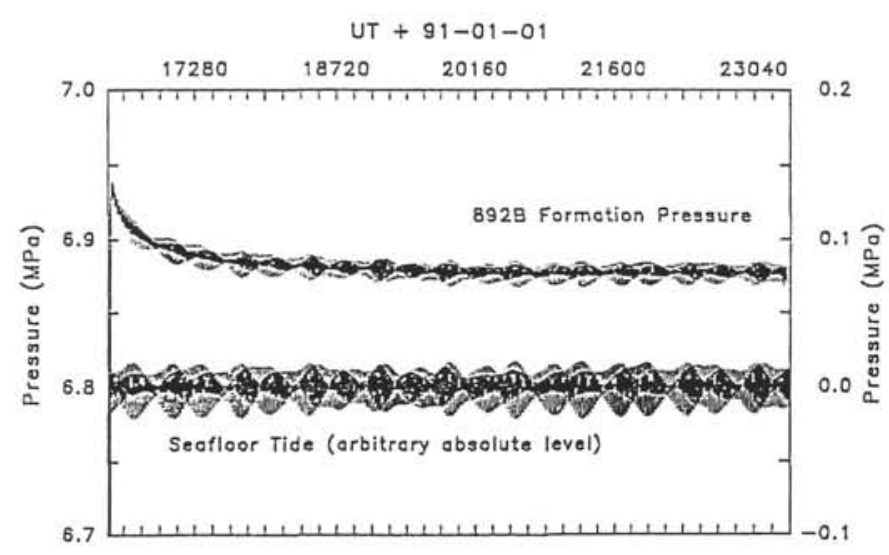

Figure 7. Pressure vs. time in Hole 892B. Seafloor pressure is determined from absolute pressure measurements in the hole and differential pressure (hole vs. seafloor) data collected 10 months after shut-in. From Davis et al. (this volume).

ductivities is sufficient to focus flow along high-permeability zones (Screaton et al., 1990). The lower conductivities are characteristic of compaction-induced intergranular permeability in fine-grained marine sediments (Clukey and Silva, 1982). The higher values appear to reflect fracture-based conductivity, as indicated by their pore pressure-dependence.

Brown (this volume) demonstrates that the hanging wall at Site $892(<68 \mathrm{mbsf})$ is characterized by low hydraulic conductivities $\left(<10^{-7} \mathrm{~cm} \mathrm{~s}^{-1}\right)$ that show modest changes with reduction in void ratio (Fig. 8A) and variations in effective stress (Fig. 8B). In contrast, the fault zone/footwall exhibits significantly higher hydraulic conductivities $\left(\sim 10^{-6}\right.$ to $\left.10^{-5} \mathrm{~cm} \mathrm{~s}^{-1}\right)$ at low effective stress (high pore pressures; Fig. 8B). These latter sediments, which are strongly sheared and show more evidence of cementation or, perhaps, strain-hardening, also exhibit dramatic reductions in conductivity with relatively small increases in confining stress (Fig. 8A). Brown (this volume) interprets these behaviors to indicate that permeability in the sheared/ faulted footwall is controlled by microfractures that dilate when $\lambda *=$ $0.40-0.80$. In the hanging wall, however, sediment responds plastically to stress variations, and flow is accommodated interstitially rather than by fractures, so that permeability is less affected by pore pressure and changes in effective stress. These data imply that when pore pressures decline to near-hydrostatic levels, micro-fractures in the fault-zone close, permeability declines, and flow is retarded. As a result, significant overpressures are required to maintain the high conductivity of the active flow zones.

\section{Field Determinations}

The pressure dependence of hydraulic conductivity indicated by laboratory studies is confirmed by field tests, although the conductivity values, derived from transmissivity results, are highly dependent upon the thickness of the active flow zone. On the basis of a packer test at Site 892 , Screaton et al. (this volume) estimated conductivity of $6.0 \times 10^{-5}$ to $1.4 \times 10^{-2} \mathrm{~cm} \mathrm{~s}^{-1}$ at a background pressure $250-325$ $\mathrm{kPa}$ above hydrostatic $(\lambda *=0.4-0.5)$, when fractures were apparently open (constant-rate injection tests run while the packer was set indicate that fractures close at pore pressures $315-325 \mathrm{kPa}$ above hydrostatic). Ten months later, the pressure at the Site 892 CORK had declined to $13 \mathrm{kPa}$ above hydrostatic $\left(\lambda^{*}=0.02\right.$; Fig. 7$)$, and fractures had closed. Pump tests under these conditions yielded hydraulic conductivities of $2.5 \times 10^{-7}$ to $1.2 \times 10^{-6} \mathrm{~cm} \mathrm{~s}^{-1}$.

Although the packer tests yielded hydraulic conductivities $3-4$ orders of magnitude greater than maximum estimates based on laboratory studies, the reader is reminded that in situ determinations probably reflect scales of fracture permeability which cannot be du- 
plicated in experimental samples and that the applied stress fields are certainly not identical. Given that both field and laboratory tests indicate pressure-dependent permeability and suggest fracture closure stress values between $\sim 315 \mathrm{kPa}$ (in situ) and $120-260 \mathrm{kPa}$ (laboratory; Brown, this volume), the two data sets are remarkably consistent.

\section{MEASURED AND CALCULATED FLUID DISCHARGE RATES}

Fault-related flow rates may differ substantially from calculated, regional expulsion rates (above), because the simple fluid inventory model assumes vertical fluid loss while it is clear that flow advects laterally along shallowly-dipping fault zones, and because the model does not differentiate between dispersed and focused flow. Although several seafloor measurements of fluid discharge at vent sites on the Oregon margin were reported by Carson et al. (1990; $1 \times 10^{-6}$ to $6 \times$ $10^{-6} \mathrm{~m}^{3} \mathrm{~m}^{-2} \mathrm{~s}^{-1} ; 3.1 \times 10^{4}$ to $1.9 \times 10^{5} \mathrm{~mm} / \mathrm{yr}^{-1}$ ), only the flow measurement by Linke et al. (1994) west of Hole 892B is directly comparable to the Leg 146 drilling results. That determination, made with a thermal flow meter at the bioherm that is inferred to lie on the surface trace of the fault penetrated at Site 892, yielded a discharge rate of 2.0 $\times 10^{-5} \mathrm{~m}^{3} \mathrm{~s}^{-1} \mathrm{~m}^{2}\left(6.3 \times 10^{5} \mathrm{~mm} \mathrm{yr}^{-1}\right)$.

It is difficult to compare borehole results with the flow measurement made at the bioherm, for fluid is not expelled uniformly along the strike of the surficial fault trace. Rather, semi-isolated seeps occur (indicated by distinct concentrations of clams and bacterial mats), which suggest that flow might be focused near the surface, perhaps by the massive carbonate cementation that has occurred at this site.

Calculated fault-zone discharge, based either on hydrogeologic parameters or thermal modeling, is sensitive to the thickness of the active flow zone. At Site 892, the response of post-drilling, downhole thermistors across the active interval at $100 \mathrm{mbsf}$ (Davis et al., this volume) constrains flow to much less than $24 \mathrm{~m}$, and Davis argues, based on organic geochemical anomalies, that active flow may be limited to an interval as narrow as $2 \mathrm{~m}$. Calculated discharge rates for these endmembers are listed in Table 1.

The hydrogeologically-constrained discharge estimate (Screaton et al., in press) is conservative if the operative hydraulic head exceeds the one-half lithostatic pressure gradient $\left(>0.75\right.$ to $\left.1.0 \mathrm{kPa} \mathrm{m}^{-1}\right)$ measured during the packer slug tests, for transmissivity is pressure-dependent (Screaton et al., this volume). On the other hand, thermal modeling demonstrates that flow is episodic, so sub-lithostatic pressures must occur and are probably appropriate to a time-averaged estimate for darcian discharge. The in situ pressure and transmissivities determined during the packer slug tests are consistent with the thermal data for time-averaged ( $\leq 1 \mathrm{k} . \mathrm{y}$.) flow along a $2 \mathrm{~m}$-thick fault zone required for the observed shoaling of the BSR at Site $892\left(\sim 1 \times 10^{-6}\right.$ $\mathrm{m}^{3} \mathrm{~s}^{-1} \mathrm{~m}^{-2} ; 3.2 \times 10^{4} \mathrm{~mm} / \mathrm{yr}$; Davis et al., this volume).

The episodic nature of flow at Site 892 is established by local temperature anomalies recorded during drilling (Westbrook, Carson, Musgrave, et al., 1994; Foucher et al., this volume) and during postdrilling shut-in (Davis et al., this volume). Analysis of the latter "flow event" that is evidenced by a rise of $4^{\circ} \mathrm{C}$ over a 5.5 month period at $100 \mathrm{mbsf}$ (but not at lesser or greater depths), may provide constraints on the duration and rate of flow. Numerical modeling indicates that a transient source of heat is necessary for the temperature inversion to occur (Fig. 9). The amplitude of the anomaly requires a flow rate of at least $3 \times 10^{-5} \mathrm{~m}^{3} \mathrm{~s}^{-1} \mathrm{~m}^{-2}\left(9.5 \times 10^{5} \mathrm{~mm} / \mathrm{yr}\right)$ over a 0.5 -yr period. This discharge rate is significantly higher than the "average" rate $\left(\sim 1 \times 10^{-}\right.$ ${ }^{6} \mathrm{~m}^{3} \mathrm{~s}^{-1} \mathrm{~m}^{-2} ; 3.2 \times 10^{4} \mathrm{~mm} / \mathrm{yr}$ ) of flow required for local shoaling of the BSR. To reconcile these disparate data, Davis et al. (this volume) infer that the average flow must be the sum of repeated, short-lived, local flow events induced by episodic fluctuations in fluid pressure and, because of the dependency outlined by Screaton et al. (this volume), variations in fault-zone transmissivity. Alternatively, the short-term, rapid flow might reflect an anomalous, local pressure gradient induced by the observed reduction of pore pressure in the hole. Episodic flow on an intermediate time frame, however, seems likely; Davis et al. (this volume) note that the observed seafloor heat flow anomaly across the fault does not differentiate the footwall from the hanging
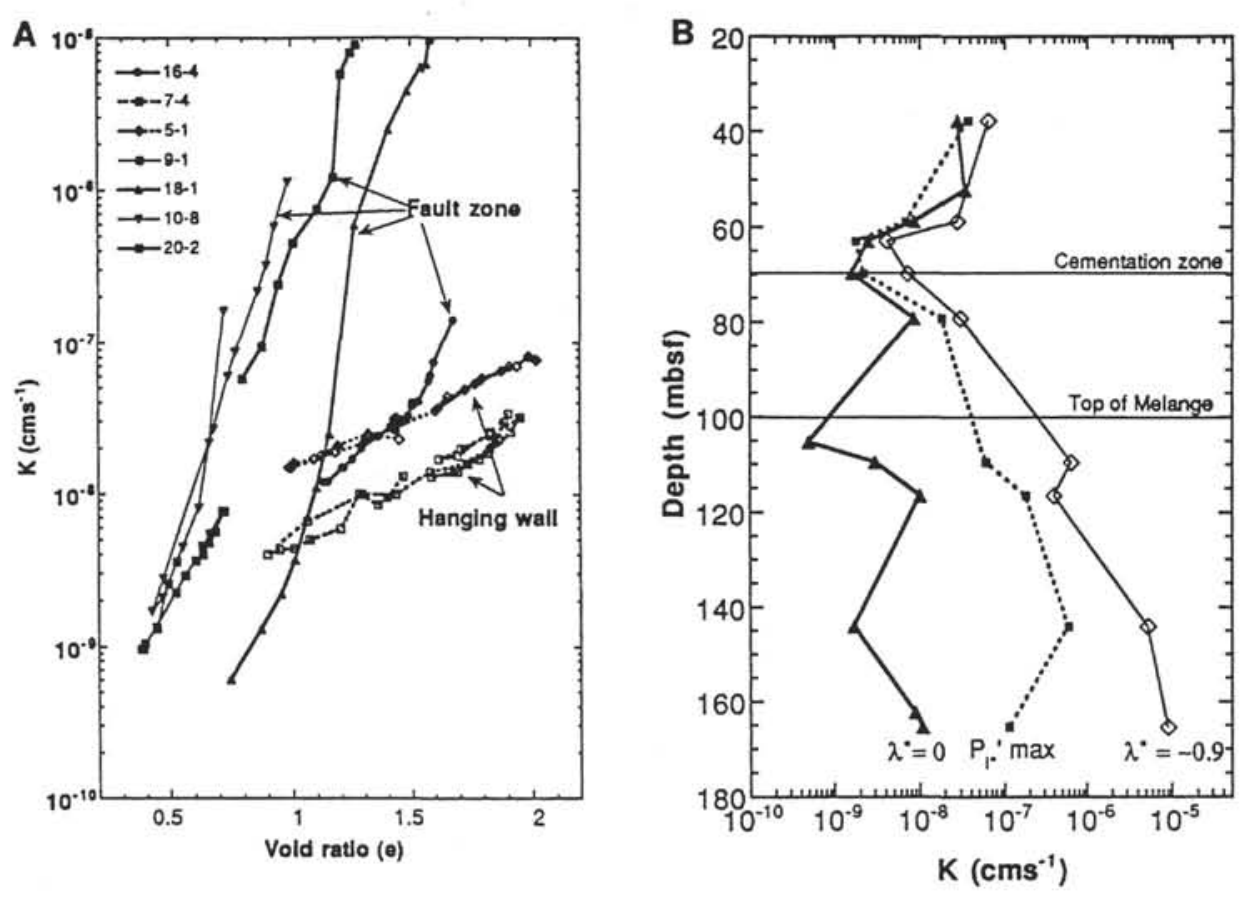

Figure 8. A. Summary of hydraulic conductivity $(\log K)$ vs. void ratio (e) relationships. Note the differences in slope between the hanging wall and fault zone samples. B. The variation of conductivity $(\mathrm{K})$ with depth and degree of overpressuring $\left(\lambda^{*}\right)$. Note the strong coupling of the fault zone $(>70 \mathrm{mbsf})$ hydraulic conductivity response to changes in fluid pressure. From Brown (this volume). 
Table 1. Calculated specific fluid discharge on Site 892 fault zone at 100 mbsf.

\begin{tabular}{|c|c|c|c|}
\hline \multirow[b]{2}{*}{ Source } & \multirow[b]{2}{*}{ Basis of estimate } & \multicolumn{2}{|c|}{$\begin{array}{l}\text { Calculated discharge }\left(\mathrm{m}^{3} \mathrm{~s}^{-1} \mathrm{~m}^{-2}\right) \text { assuming } \\
\text { flow zone thickness of: }\end{array}$} \\
\hline & & $24 \mathrm{~m}$ & $2 \mathrm{~m}$ \\
\hline Screaton et al. (this volume) & $\begin{array}{l}\text { Packer (slug) test transmissivity }=\left(8 \times 10^{-6} \text { to } 92 \times 10^{-6} \mathrm{~m}^{2} \mathrm{~s}^{-1}\right) \\
\text { pressure gradient }=\left(0.75 \text { to } 1.0 \mathrm{kPa} \mathrm{m}^{-1}\right)\end{array}$ & $\begin{array}{l}2.7 \times 10^{-8} \text { to } 3.1 \times 10^{-7} \\
\left(8.5 \times 10^{-2} \text { to } 9.8 \times 10^{3}\right)\end{array}$ & $\begin{array}{l}3.3 \times 10^{-7} \text { to } 3.8 \times 10^{-6} \\
\left(1 \times 10^{4} \text { to } 1.2 \times 10^{5} \mathrm{~mm} / \mathrm{yr}\right)\end{array}$ \\
\hline Davis et al. (this volume) & Finite element model of transient thermal anomaly & $\begin{array}{l}2.5 \times 10^{-6} \\
\left(7.9 \times 10^{4} \mathrm{~mm} / \mathrm{yr}\right)\end{array}$ & $\begin{array}{l}\geq 3.0 \times 10^{-5} \\
\left(9.5 \times 10^{5} \mathrm{~mm} / \mathrm{yr}\right)\end{array}$ \\
\hline
\end{tabular}

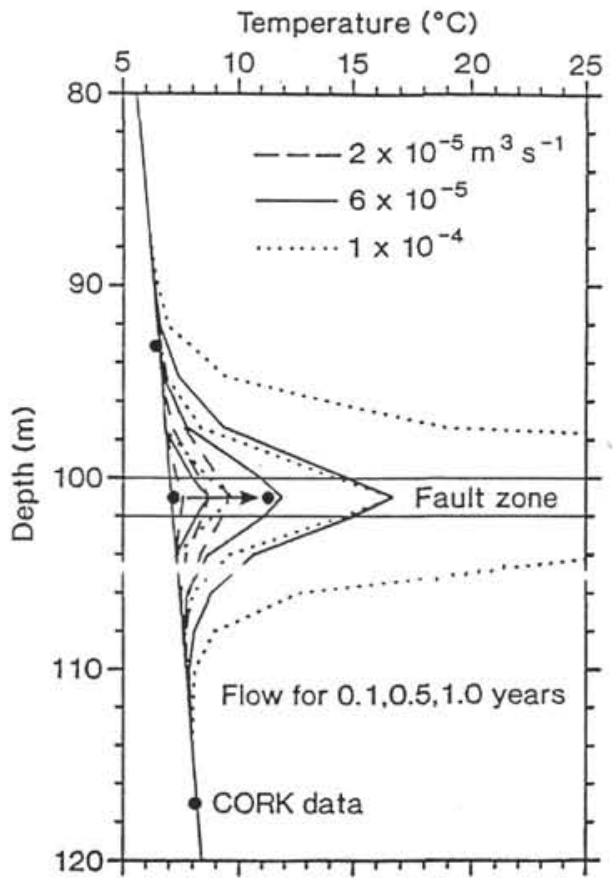

Figure 9. Temperature-depth profile at Hole $892 \mathrm{~B}$ calculated by Davis et al. (this volume) soon after step-wise initiation of fluid flow. Profiles are shown for three different rates of flow, and at $0.1,0.5$, and $1.0 \mathrm{yr}$ after initiation of flow. The model results are compared to CORK thermistor data, including that from thermistor 10 , which increased $4^{\circ} \mathrm{C}$ over 5.5 months. The coincidence of the fault zone and thermistor 10 is assumed.

wall, as would occur if flow up the fault zone were steady for more than a few hundred years.

\section{SUMMARY}

Data from Leg 146 and from the CORK installation at Site 892 on the Cascadia margin provide the most comprehensive characterization to date of active fluid flow in a modern accretionary prism. Numerical modeling of the Vancouver margin (Bekins and Dreiss, 1992; Hyndman et al., 1993b; Wang et al., 1993; Wang, 1994) and evaluation of the fluid inventory off Oregon, as defined by the $P$ wave velocity distribution, all indicate that fluid is lost from the westernmost $15-30 \mathrm{~km}$ of the Cascadia prism at rates ranging from $\sim 0-4$ $\times 10^{-11} \mathrm{~m}^{3} \mathrm{~m}^{-2} \mathrm{~s}^{-1}(0-1.3 \mathrm{~mm} / \mathrm{yr})$. Unlike the modeling result, howev$\mathrm{er}$, that predicts an exponential decline in fluid loss from the toe of the prism eastward (Bekins and Dreiss, 1992), the fluid inventory off Oregon suggests nearly constant fluid expulsion $\left(3.2 \times 10^{-12}-2.9 \times\right.$ $\left.10^{-11} \mathrm{~m}^{3} \mathrm{~m}^{-2} \mathrm{~s}^{-1} ; 0.1-0.9 \mathrm{~mm} / \mathrm{yr}\right)$ across the lowermost $18 \mathrm{~km}$ of the accretionary prism. The uncertainty in the data neither preclude nor confirm the pattern of maximum discharge $20-30 \mathrm{~km}$ east of the toe proposed by Hyndman et al. (1993b) for the Vancouver Island margin.

The inventory of pore-water volume is improved over a previous attempt to assess the water budget on the Oregon margin (Carson et al., 1991), in large part because of improved seismic velocity analysis (Cochrane et al., 1994b), and use of better velocity-porosity relationships (Hyndman et al., 1993a; Jarrard et al., this volume). It is tempting to combine these data with flow rates derived for the fault zone at Site 852 , to extrapolate and assess the importance of fracture-centered flow to the dewatering of the lower prism. However, the temporal and spatial heterogeneity of fault-controlled flow preclude realistic estimates. It is likely that reliable evaluation of the fault-flow component will come only as we assess the dispersed fluid discharge and subtract that element from the total pore fluid inventory.

Consolidation tests, experimental $P$-wave velocity determinations on samples collected from Sites 891 and 892 , and seismic modeling suggest that fluid-active fault zones are characterized by fluid pressures $\geq 70 \%$ of the lithostatic stress (Brown, this volume; Moore et al., this volume; Moran et al., this volume; Tobin et al., this volume). A packer test in an active thrust fault at Site 892 (Screaton et al., this volume) directly measured a somewhat lesser overpressure of $40 \%$ $50 \%$ of the lithostatic load.

Thermal anomalies define episodic flow events which, in turn, require pressure cycling (Davis et al., this volume; Foucher et al., this volume). Modeling of the thermal inversion recorded by the CORK in the faulted interval of Site 892 suggests a minimum flow of $3 \times$ $10^{-5} \mathrm{~m}^{3} \mathrm{~m}^{-2} \mathrm{~s}^{-1}\left(9.5 \times 10^{5} \mathrm{~mm} / \mathrm{yr}\right)$ for a duration of $\sim 0.5 \mathrm{yr}$. Whether this "flow event" is natural or induced by the post-drilling pressure reduction in the hole, it establishes either the occurrence or feasibility of flow that is significantly greater than the average flow rate $(\sim 1 \times$ $10^{-6} \mathrm{~m}^{3} \mathrm{~m}^{-2} \mathrm{~s}^{-1} ; 3.2 \times 10^{4} \mathrm{~mm} / \mathrm{yr}$ ) determined from local shoaling of the BSR, and from calculated darcian flow based on pressures and permeabilities measured at Site 892 (Screaton et al., this volume).

Both laboratory consolidation-permeability tests (Brown, this volume) and in situ hydrogeologic experiments (Screaton et al., in press) define a pressure-dependency of fault-zone hydraulic transmissivity. Flow in the fault zone penetrated at Site 892 is localized by dilation of fractures that yield transmissivities at least two orders of magnitude greater than transmissivity values in adjacent, unfractured sections or in the same interval when pore pressure is reduced to hydrostatic and the fractures close. Fractures remain open (and transmissivity remains high) at sublithostatic pressures. The field tests suggest fracture closure at $\sim 320 \mathrm{kPa}(\lambda * \sim 0.5)$, whereas the laboratory data indicate closure at effective stresses above $120-260 \mathrm{kPa}$. The dependence of fracture permeability on pore pressure and the effective confining stress implies a non-linear flow response to pressure fluctuations in the fracture zone.

\section{ACKNOWLEDGMENTS}

We thank the Shipboard Scientific Party of Leg 146 for the efforts required to document fluid flow on the Cascadia Margin. This synthesis draws particularly on the results of the logging and physical properties scientists. During the cruise, we relied heavily on the ex- 
pertise of ODP Operations Superintendent Glen Foss and ODP Development Engineer Tom Pettigrew to keep the holes open and install CORKs at Sites 889 and 892 . Much of what we know about flow in the faulted interval at Site 892 came from data collected and tests conducted 10 months after drilling using the submersible Alvin. We thank the individuals instrumental in that effort: E. Screaton, G. Lennon, M. Schlueter, C. Wagner, K. Becker, E. Davis, and the Atlantis II/Alvin staffs. This manuscript was improved significantly by reviews from L. Kulm, E. Davis, and R. Hyndman.

\section{REFERENCES}

Bangs, N.L.B., Westbrook, G.K., Ladd, J.W., and Buhl, P., 1990. Seismic velocities from the Barbados Ridge Complex: indicators of high pore fluid pressures in an accretionary complex. J. Geophys. Res., 95:87678782.

Bekins, B.A., and Dreiss, S.J., 1992. A simplified analysis of parameters controlling dewatering in accretionary prisms. Earth Planet. Sci. Lett., 109:275-287.

Bray, C.J., and Karig, D.E., 1985. Porosity of sediments in accretionary prisms, and some implications for dewatering processes. J. Geophys. Res., 90:768-778.

Brown, K.M., Bekins, B., Clennell, B., Dewhurst, D., and Westbrook, G., 1994. Heterogeneous hydrofracture development and accretionary fault dynamics. Geology, 22:259-262.

Carson, B., Holmes, M.L., Umstattd, K., Strasser, J.C., and Johnson, H.P., 1991. Fluid expulsion from the Cascadia accretionary prism: evidence from porosity distribution, direct measurements, and GLORIA imagery. Philos. Trans. R. Soc. London A, 335:331-340.

Carson, B., Seke, E., Paskevich, V., and Holmes, M.L., 1994. Fluid expulsion sites on the Cascadia Accretionary Prism: mapping diagenetic deposits with processed Gloria imagery. J. Geophys. Res., 99:1195911969.

Carson, B., Suess, E., and Strasser, J.C., 1990. Fluid flow and mass flux determinations at vent sites on the Cascadia margin accretionary prism. $J$. Geophys. Res., 95:8891-8897.

Clukey, E.C., and Silva, A.J., 1982. Permeability of deep-sea clays: Northwestern Atlantic. Mar. Geotechnol., 5:1-25.

Cochrane, G.R., Lewis, B.T.R., and McClain, K.J., 1988. Structure and subduction processes along the Oregon-Washington Margin. Pure Appl. Geophys., 128:767-800.

Cochrane, G.R., MacKay, M.E., Moore, G.F., and Moore, J.C., 1994a. Consolidation and deformation of sediments at the toe of the central Oregon accretionary prism from multichannel seismic data. In Westbrook, G.K., Carson, B., Musgrave, R.J., et al., Proc. ODP, Init. Repts., 146 (Pt. 1): College Station, TX (Ocean Drilling Program), 421-426.

Cochrane, G.R., Moore, J.C., MacKay, M.E., and Moore, G.F., 1994b. Velocity and inferred porosity model of the Oregon accretionary prism from multichannel seismic reflection data: implications on sediment dewatering and overpressure. J. Geophys. Res., 99:7033-7043.

Davis, E.E., Becker, K., Pettigrew, T., Carson, B., and MacDonald, R., 1992. CORK: a hydrologic seal and downhole observatory for deep-ocean boreholes. In Davis, E.E., Mottl, M.J., Fisher, A.T., et al., Proc. ODP. Init. Repts., 139: College Station, TX (Ocean Drilling Program), 43-53.
Davis, E.E., and Hyndman, R.D., 1989. Accretion and recent deformation of sediments along the northern Cascadia subduction zone. Geol. Soc. Am. Bull., 101:1465-1480.

Davis, E.E., Mottl, M.J., Fisher, A.T., et al., 1992. Proc. ODP, Init. Repts., 139: College Station, TX (Ocean Drilling Program).

Hamilton, E.L., 1978. Sound velocity-density relations in sea-floor sediments and rocks. J. Acoust. Soc. Am., 63:366-377.

Hyndman, R.D., Moore, G.F., and Moran, K., 1993a. Velocity, porosity, and pore-fluid loss from the Nankai subduction zone accretionary prism. In Hill, I.A., Taira, A., Firth, J.V., et al., Proc. ODP, Sci. Results, 131: College Station, TX (Ocean Drilling Program), 211-220.

Hyndman, R.D., Wang, K., Yuan, T., and Spence, G.D., 1993b. Tectonic sediment thickening, fluid expulsion, and the thermal regime of subduction zone accretionary prisms: the Cascadia margin off Vancouver Island. J. Geophys. Res., 98:21865-21876.

Kulm, L.D., and Fowler, G.A., 1974. Oregon continental margin structure and stratigraphy: a test of the imbricate thrust model. $\ln$ Burke, C.A., and Drake, C.L. (Eds.), The Geology of Continental Margins: New York (Springer), 261-284.

Lewis, B.T.R., 1991. Changes in P and S velocities caused by subduction related sediment accretion off Washington/Oregon. In Hovem, J.M., Richardson, M.D., and Stoll, R.D. (Eds.), Shear Waves in Marine Sediments: Boston (Kluwer), 379-386.

Linke, P., Suess, E., Torres, M., Martens, V., Rugh, W.D., Ziebis, W., and Kulm, L.D., 1994. In situ measurement of fluid flow from cold seeps at active continental margins. Deep-Sea Res., 41:721-739.

MacKay, M.E., Moore, G.F., Cochrane, G.R., Moore, J.C., and Kulm, L.D., 1992. Landward vergence and oblique structural trends in the Oregon margin accretionary prism: implications and effect on fluid flow. Earth Planet. Sci. Lett., 109:477-491.

Moore, J.C., Moran, K., and MacKay, M.E., 1994. Fluid pressure estimates from the frontal thrust, Oregon accretionary prism. Geol. Soc. Am. Abstr. Prog., 26:A-457.

Moore, J.C., and Vrolijk, P., 1992. Fluids in accretionary prisms. Rev. Geophys., 30:113-135.

Screaton, E.J., Carson, B., and Lennon, G.P., in press. Hydrogeologic properties of a thrust fault within the Oregon accretionary prism. J. Geophys Res.

Screaton, E.J., Wuthrich, D.R., and Dreiss, S.J., 1990. Permeabilities, fluid pressures, and flow rates in the Barbados Ridge Complex. J. Geophys. Res., 95:8997-9007.

Wang, K., 1994. Kinematic models of dewatering accretionary prisms. $J$. Geophys Res., 99:4429-4438.

Wang, K., Hyndman, R.D., and Davis, E.E., 1993. Thermal effects of sediment thickening and fluid expulsion in accretionary prisms: model and parameter analysis. J. Geophys. Res., 98:9975-9984.

Westbrook, G.K., Carson, B., Musgrave, R.J., et al., 1994. Proc. ODP, Init. Repts., 146 (Pt. 1): College Station, TX (Ocean Drilling Program).

Yuan, T., Spence, G.D., and Hyndman, R.D., 1994. Seismic velocities and inferred porosities in the accretionary wedge sediments at the Cascadia Margin. J. Geophys. Res., 99:4413-4427.

\footnotetext{
Date of initial receipt: 1 March 1995

Date of acceptance: 25 May 1995

Ms 146SR-240
} 